\title{
STUDIES ON A SMALL COLLECTION OF PLANORBID SNAILS FROM SOUTHERN SOUTH AMERICA
}

\author{
Frederico S. Barbosa and Dalva A. Mello
}

\begin{abstract}
Snails belonging to Biomphalaria genus were collected from some regions of southern South America as follows: Resistencia, province of Chaco, Argentina; Assumpcion, Paraguay; Department of Maldonado of Caneloni, Uruguay; and Pôrto Alegre, Rio Grande do Sul, Brazil. The material was classified as Biomphalaria peregrina (Orbigny) twice from Uruguay and once in Brazil; B. tenagophila (Orbigny), from Argentina and Brazil; and B. straminea (Dunker) in Paraguay.
\end{abstract}

Negative results were obtained from the exposition of the above refered snail specimens to miracidia of $\mathrm{S}$. mansoni from Pernambuco, Brazil.

During the month of January 1969 the junior Author travelling in southern South America, made a limited number of ccllections of fresh-water snails belonging to the Planorbid genus Biomphalaria.

Part of the snails was extended with menthol crystals and fixed locally in alcohol $\mathbf{7 0 \%}$, while some other specimens were brought alive to the laboratory in Recife where the present studies were made. Upon arrival the alive snails were put in tanks to breed.

Preserved snails were dissected for classification. Alive snails were each exposed to ten miracidia of a local strain of Schistosoma mansoni. In all the infection experiments a highly susceptible strain of Biomphalaria glabrata, from Paulista (Pernambuco), was used as control.

Snails exposed to the infection were kept in tanks and examined for cercariae by exposition to a strong source of light beginning the 20th day after the infection
After 40 days the snails were crushed and examined for infection.

The temperature of the water, during the experiments, varied from 24 to $26^{\circ} \mathrm{C}$.

The following studies and observations were made.

\section{PARAGUAY}

Twenty-one snails were collected in drainage ditches in the streets of "Bairro Capitalizador", Assumption. The water in the ditches was dark, highly polluted and the bottom was muddy. Aquatic plants were not present. The habitat was not permanent since the water was mainly originated from periodical rains fallen few days before. Snails of the genus Pomacea (Ampulariidae) were seen thriving along with the Biomphalaria. The shell and the anatomy of the snails collected correspond to the species Biomphalaria straminea (Dunker). That species in known from Venezuela, the Guianas and Brazil, reaching to about $20^{\circ} \mathrm{S}$. It was recently found in Colombia (1). The

School of Medicine, University of Pernambuco, Recife, Brazil Adress: I.B.T.M., Caixa Postal 1859. Rio, Guanabara. 
species is for the first time recorded in Paraguay.

The exposition of 17 specimens of the Paraguay strain of $B$. straminea to miracidia of $S$. mansoni resulted negative: none of the snails got the infection.

\section{ARGENTINA}

A collection of snails was made in the town of Resistencia, capital of the province of Chaco, northern Argentina. Snails were collected in a large swamp at the end of street Brazil in the outskirts of the town. The habitat seemed to be permanent: the water showed high turbidity and several aquatic plants were present. Other snails found were specimens of Drepanotrema sp. (Planorbidae) and of Pomacea sp (Ampullariidae). The specimens of Biomphalaria collected were classified as $B$. tenagophila (Orbigny). This species was already known from Argentina, Paraguay, Uruguay, Brazil (about $15 .^{\circ}$ southward), Bolivia and Peru (7).

The exposition of 18 specimens of the Argentina strain of $B$. tenagophila to miracidia of $S$. mansoni gave negative results.

\section{URUGUAY}

Two collections were made in this country: one in the town of San Carlos (Departamento de Maldonado) and other about $20 \mathrm{~km}$ northern of Montevideo (Departamento de Caneloni). The specimens of Maldonado were collected in a small ditch in a street near the center of the small town of San Carlos. The snails were living in a small temporary pool without aquatic plants and with no other snails. The bottom was clayey. The snails from Caneloni were found in a permanent stream known as Toledo Chico. The water was clear, the bottom muddy and many aquatic plants were present. One specimen of Lymnea $\mathrm{sp}$. was found among the planorbids. Snails from both places in Uruguay were classified as Biomphalaria peregrina (Orbigny): 22 specimens were collected in Maldonado and 56 specimens in Caneloni. The species has large geogaphical distribution. It has been record- ed from Ecuador, Bolivia, Chile, Brazil, Paraguay, Uruguay, and Argentina west of the Andes from about the Equator to $42 .^{\circ} \mathrm{S}$, and east of the Andes from about $15 .^{\circ}$ to $41 .{ }^{\circ} \mathrm{S}(8)$.

Negative results were obtained from the exposition of 17 snail specimens of $B$. peregrina from Maldonado and 1 specimen from Caneloni to miracidia of $S$. mansoni.

\section{BRAZIL}

One collection was made in the southern Brazilian state of Rio Grande do Sul. The place collected was near the airport of Porto Alegre where two species of Biomphalaria were found. The habitat is an extensive permanent swamp located at the edgde of the highway leading to the airport. The water showed some turbidity, the bottcm was muddy and many aquatic plants were present. Snails of the families Physidae and Ampullariidae were found. Numerous empty shells of Biomphalaria tenagophila (Orbigny) plus 3 alive specimens of $B$. peregrina were collected. Of those only one specimen was alive when arrived in Recife. This specimen was exposed to miracidia of $S$. mansoni and was found dead few days latter. Obviously the classification of both species was made by shell features.

\section{COMMENTS}

Two species represented in the small collection of planorbid snails studied in the present paper are well known as vectors of schistosomiasis mansoni: $B$. straminea chiefly in northeastern Brazil and $B$. tenagophila in the southern part of this country. $B$. peregrina can be considered as a potential vector of Schistosomiasis according to laboratory infection data given by Barbosa, Barbosa \& Rodriguez (5) for specimens from Ecuador, by Richards (9) for specimens from Puerto Rico, and by Paraense \& Correa (7) for specimens from Paraná, Brazil.

Other potential intermediate hosts of $S$. mansoni are known to occur in reglons where the human infection has never become established $(3,4,6)$. 
Results presented in the current paper do not exclude the possibility that the snail strains used for the infection experiments could serve as potential intermediate hosts for schistosomiasis.

The capability of a snail to act as a suitable host depends on both snail and parasite. $B$. straminea, the well known vector of schistosomiasis in northeastern
Brazil, behave differently in northern South America when submitted to laboratory infections. Barbosa (2) recently showed that $B$. straminea from Manaus, Brazil, was fully resistant to the infection with $S$. mansoni from Pernambuco and that the strain of the same snail species from Cali, Colombia, (1) could be hardly infected with $S$. mansoni from the same origin.

\section{R E S U M O}

Caramujos do gênero Biomphalaria (Planorbidae) foram coletados ao sul da América do Sul, nos seguintes locais: Resistência, provincia do Chaco, Argentina; Assunção, capital do Paraguai; provincias de Maldonado e de Caneloni, Uruguai; e Pôrto Alegre, capital do estado do Rio Grande do Sul, Brasil. O material foi classificado como se segue: Biomphalaria peregrina (Orbigny), duas coletas no Uruguai e uma no Brasil; B. tenagophila (Orbigny), na Argentina e no Brasil; e B. straminea (Dunker), no Paraguai.

Resultaram negativas tôdas as tentativas feitas em laboratório para infectar as espécies acima mencionadas com a cêpa de Schistosoma mansoni de Pernambuco.

\section{$R E S U M O$}

1. BARBOSA, F.S. - Biomphalaria straminea (Dunker) en Colombia. Antioquia Medica, 18: 753-758, 1968.

2. BARBOSA, F.S. - A note on Biomphalaria straminea (Dunker, 1848) from Manaus, state of Amazonas, Brazil. Rev. Soc. Bras. Med. Trop., 2: 77-78, 1968.

3. BARBOSA, F.S. \& BARBOSA, I. Tropicorbis chilensis from Santiago, Chile, a potential intermediate host of Schistosoma mansoni. Bol. Chileno Parasitol., 13: 7-9, 1968.

4. BARBOSA, F. S., BARBOSA, I. \& CARNEIRO, E. - Description of Australorbis sericeus (Dunker), a possible intermediate host of Schistosoma mansoni in Ecuador. Ann. Trop. Med. Parasitol., 57: 52-58, 1963.

5. BARBOSA, F. S. BARBOSA, I. \& RODRIGUEZ, J. D. - Tropicorbis philippianus (Dunker) a potential in- termediate host of Schistosoma mansoni in Ecuador. Jour. Parasitol., 44: 622, 1958 .

6. CRAM, E. B., JONES, M. F. \& WRIGHT, W. H. - A potencial intermediate host of Schistosoma mansoni. Science: 101: 302, 1945.

7. P.A.H.O. - A Guide for the Identification of the Snail Hosts of Schistosomiasis in the Americas. Scientific Publication N. ${ }^{\circ} 168$. Washington. D.C., U.S. , 1968.

8. PARAENSE, W.L. -_. The synonymy and distribution of Biomphalaria peregrina in the Neotropical region. Rev. Brasil. Biol., 26: 269-296, 1966.

9. RICHARDS, C.S. ...- Infectivity of Schistosoma mansoni for Puerto Rican mollusks, including a new potential intermediate host. $A m$. J. Trop. Med. Hyg., 12: 26-33, 1963. 